\title{
Water intake of hyposalemic anosmic rats
}

WILLIAM B. VANCE

INDIANA UNIVERSITY

While the olfactory bulbs appear to be important in sodium thirst, animals with olfactory bulbs transected show an increased water intake following sodium depletion which is indistinguishable from unoperated controls.

Intravenous, intragastric, intraperitoneal, and subcutaneous injections of hypertonic sodium chloride all give rise to an increase in water intake. This well known phenomenon of "sodium thirst" has led to the formulation of an osmometric theory which states that an increase in extracellular tonicity draws water from cells producing cell shrinkage which in turn serves as the stimulus for drinking (see Wolf, 1958). There is further, strong evidence that specific osmoreceptors are located in the hypothalamus. Injections of hypertonic sodium chloride into the hypothalamus of goats produces profusedrinking (Anderson, 1953), and single neurons of the hypothalamus respond to hypertonic sodium chloride injected through the carotid artery (Cross \& Green, 1959). In addition, the osmotic control of antidiuretic hormone release (Verney, 1947) seems to depend only on the integrity of the hypothalamus (Woods et al, 1966). Many limbic structures also show activation during carotid artery sodium chloride infusion (Wayner, 1967), and Sundsten \& Sawyer (1959) have presented convincing evidence for the existence of osmoreceptive units in the olfactory bulb. The olfactory bulbs have been shown to be particularly important in sodium thirst since bulb transection severely affects both the onset of drinking and the total volume drunk (Vance, 1967).

One of the chief difficulties with the cellular dehydration theory has been the observation that sodium depletion, which results in an overhydration of cells, also produces an increased water intake in man (Gregerson et al, 1951; McCance, 1936), the dog (Cizek et al, 1951; Holmes, 1940; Holmes \& Cizek, 1951), the rabbit (Huang, 1955), and the rat (Semple, 1952). Insulin, which produces cellular hydration, also increases water intake (Novin, 1964).

In the interest of preserving a single (osmometric) theory for the thirst mechanism, two possibilities have been offered to account for hyposalemic thirst. Verney (1947) suggested that the osmoreceptors might accomodate to the lower tonicity of the extracellular fluid and thus respond at a lower range, although as Wolf (1950) has pointed out, one would expect a similar accomodation in hypersalemia. Wolf (1953), on the other hand, has suggested that the osmoreceptive cells may respond to either shrinkage or expansion and thus stimulate thirst in both hyper- and hyponatremic states.

The present investigation examines the questions of whether the olfactory bulbs, which are involved in hypernatremic drinking, are also involved in hyponatremic drinking.

Method

Ten male Wistar rats served as Ss, five controls and five experimental. The animals weighed approximately $350 \mathrm{~g}$ at the start of the experiment. Each animal was housed individually in wire mesh cages fitted with graduated drinking tubes for recording water intake. Olfactory bulb transections were made with a scalpel under Nembutol anesthesia. After a two week recovery period, all animals were given an intraperitoneal load (10\% of body weight) of isotonic sucrose which was removed through a 13 gauge needle $4 \mathrm{~h}$ later. A second dialysis with identical procedure was performed eight days later. Twenty-five days following the first dialysis each animal received a $3 \mathrm{ml}$ intraperitoneal injection of $1 \mathrm{M} \mathrm{NaCl}$. Between the first dialysis and the $\mathrm{NaCl}$ injection, the animals were maintained on a low sodium diet (General Biochemicals).

Results

Two animals in each group died as a result of the dialyses and data are presented for three animals in each group. The effects of the dialyses and low sodium diet on water intake can be seen in Fig. 1. There is an approximate $60 \%$ increase in water intake following the second dialysis for both groups, and both groups returned to normal levels after sodium injection and return to normal diet.

Discussion

The results clearly demonstrate that transection of

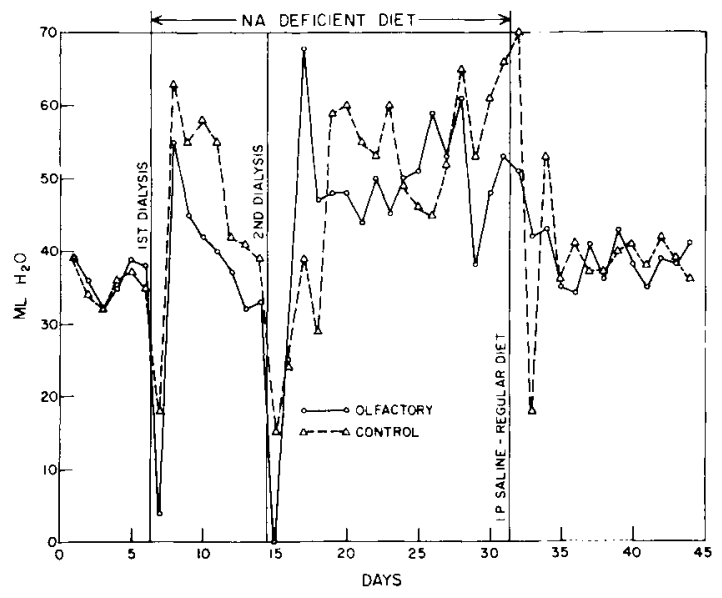

Fig. 1. Daily water intake of anosmic and normal animals before and after two intraperitoneal dialyses. 
the olfactory bulbs is without effect on hyposalemic drinking. Thus, on the assumption that olfactory osmoreceptors are important in sodium thirst, it is clear that these same receptors are not crucial in sodium deficiency drinking.

\section{References}

ANDERSON, B. The effect of injections of hypertonic $\mathrm{NaCl}$-solutions into different parts of the hypothalamus of goats. Acta physiol Scand. 1953, 28, 188-201.

CIZEK, L. J., SEMPLE, R. E., HUANG, K. C., \& GREGERSON, M. I. Effect of extracellular electrolyte depletion on water intake in dogs. Amer. J. Physiol, 1951, 164, 415.

CROSS, B. A., \& GREEN, J. D. Activity of single neurons in the hypothalamus: effect of osmotic and other stimuli. J. Physiol, 1959, 148, 554569.

GREGERSON, M. I., WALCOTT, W. W., \& CIZEK, L. J. Salt deficiency in normal humans subjects. Amer. J. Physiol, 1951, 167, 789.

HOLMES, J. H. Studies of water exchange in dogs with reduced serum electrolyte concentration. Amer. J. Physiol, 1940, 129, 384.

HOLMES, J. H., \& CIZEK, L. J. Observations on sodium chloride depletion in the dog. Amer. J. Physiol, 1951, 164, 407.

HUANG, K. C. Effect of salt depletion and fasting on water exchange in the rabbit. Amer. J. Physiol, 1955, 181, 609.

McCANCE, R. A. Experimental sodium chloride deficiency in man.Proc.
Roy. Soc., London, S.B. 1936, 119, 245.

NOVIN, D. The effect of insulin on water intake in the rat. In M. J. Wayner (Ed.), Thirst. New York: Pergamon Press, 1964. P. 180.

SUNDSTEN, J. W., \& SAWYER, C. H. Electro-encephalographic evidence of osmoreceptive elements in olfactory bulb of dog brain. Proc. Soc. Exp. Biol Med., 1959, 101, 524.

SEMPLE, R. E. Compensatory changes in the rat following removal of electrolytes by intraperitoneal dialysis. Amer. J. Physiol, 1952, 168, 55.

VANCE, W. B. Olfactory bulb resection and water intake in the white rat. Psychon Sci, 1967, 8, 131-132.

VERNEY, E. B. The antidiuretic hormone and the factors which determine its release. Proc. Roy. Soc., London, s.B., 1947, 135, 25-106.

WAYNER, M. J. Hypothalamic and limbic system activation during salt arousal of drinking. Psychon. Sci., 1967, 7, 179.

WOLF, A. V. Thirst. Sprinfield: Charles C. Thomas, 1958.

WOLF, A. V. The urinary function of the kidney. New York: Grune \& Stratton, 1950.

WOLF, A. V. Some new perspectives in renal physiology.J. Urol, 1953, $70,1-8$.

WOODS, J. W., BARD, P., \& BLEIER, R. Functional capacity of the deafferented hypothalamus: water balance and response to osmotic stimuli in the decerebrate cat and rat. J. Neurophysiol., 1966, 29, 751-767.

Note

1. This research was supported by PHS grant NB05940. 